\title{
Tropical forcing of Circumpolar Deep Water Inflow and outlet glacier thinning in the Amundsen Sea Embayment, West Antarctica
}

\author{
E.J. STEIG, ${ }^{1}$ Q. DING, ${ }^{1}$ D.S. BATTISTI, ${ }^{2,3}$ A. JENKINS ${ }^{4}$ \\ ${ }^{1}$ Department of Earth and Space Sciences and Quaternary Research Center, University of Washington, \\ Seattle, WA, USA \\ E-mail: steig@uw.edu \\ ${ }^{2}$ Department of Atmospheric Sciences, University of Washington, Seattle, WA, USA \\ ${ }^{3}$ Geophysical Institute, University of Bergen, Bergen, Norway \\ ${ }^{4}$ British Antarctic Survey, Natural Environment Research Council, Cambridge, UK
}

\begin{abstract}
Outlet glaciers draining the Antarctic ice sheet into the Amundsen Sea Embayment (ASE) have accelerated in recent decades, most likely as a result of increased melting of their ice-shelf termini by warm Circumpolar Deep Water (CDW). An ocean model forced with climate reanalysis data shows that, beginning in the early 1990s, an increase in westerly wind stress near the continental shelf edge drove an increase in CDW inflow onto the shelf. The change in local wind stress occurred predominantly in fall and early winter, associated with anomalous high sea-level pressure (SLP) to the north of the ASE and an increase in sea surface temperature (SST) in the central tropical Pacific. The SLP change is associated with geopotential height anomalies in the middle and upper troposphere, characteristic of a stationary Rossby wave response to tropical SST forcing, rather than with changes in the zonally symmetric circulation. Tropical Pacific warming similar to that of the 1990s occurred in the 1940s, and thus is a candidate for initiating the current period of ASE glacier retreat.
\end{abstract}

\section{INTRODUCTION}

Pine Island Glacier (PIG) and Thwaites Glacier, the two largest of several fast-moving outlet glaciers that drain a large fraction of the West Antarctic ice sheet (WAIS) into the Amundsen Sea Embayment (ASE), have long been recognized as critical elements of WAIS dynamics (e.g. Lingle and Clark, 1979). Hughes $(1979,1981)$ argued that it is these glaciers that make the WAIS most susceptible to large-scale collapse, which almost certainly occurred during some previous interglacial periods (Scherer and others, 1998; Naish and others, 2009; Pollard and DeConto, 2009). The inferred sensitivity of the ASE glaciers reflects their bed geometry, which deepens inland (Lythe and others, 2001), the small size of the floating ice shelves at their termini, and the direct exposure of the ice shelves to the influence of warm Circumpolar Deep Water (CDW) (Jacobs and others, 1996; Nitsche and others, 2007). In the mid-1990s it was discovered that melt rates under the PIG ice shelf are two orders of magnitude greater than under the much larger ice shelves in the Ross and Weddell Seas (Jacobs and others, 1996). Subsequent studies using satellite imagery and interferometry revealed that the grounding lines of PIG as well as Smith and Thwaites Glaciers had retreated recently (Rignot, 1998, 2001), that there was significant thinning well inland of the grounding lines (Wingham and others, 1998; Shepherd and others, 2002) and that glacier surface velocities were increasing (Joughin and others, 2003; Rignot, 2008).

Although the thinning of ASE glaciers could in part reflect changes in surface mass balance (i.e. changes in snowfall in the drainage areas), Shepherd and others (2002) showed that the magnitude of thinning is too large to be explained that way, and that the pattern of changes is consistent with the diffusive upstream migration of a force perturbation beginning at the grounding line (Schmelz and others, 2002; Payne and others, 2004; Thomas and others, 2004). This in turn is consistent with a response to the thinning of the ice shelves
(Shepherd and others, 2004) resulting from an increase in submarine melt rates due to enhanced delivery of heat from warm CDW, as had been suggested much earlier (Jacobs and others, 1992, 1996). These ideas were validated in 2010 by direct observations made by an autonomous underwater vehicle under the PIG ice shelf, which mapped the subglacial topography in great detail, and measured water temperature, salinity and oxygen content (Jenkins and others, 2010). These observations showed that CDW now floods the cavity below PIG, $>30 \mathrm{~km}$ upstream of areas that were at least partially grounded as recently as the early 1970s. At several degrees above freezing, this CDW carries enough heat to be melting the ice from below at rates in excess of $50 \mathrm{~m} \mathrm{a}^{-1}$, in good agreement with estimates independently derived from the observed ice velocities and thinning rates (e.g. Rignot and others, 2008).

Thoma and others (2008) used a regional ice-ocean model to show that recent changes in the influx of CDW in the ASE could be attributed to changes in the frequency and strength of westerly winds near the edge of the continental shelf. The timing of modelled increases in CDW influx is similar to the timing of two distinct phases of acceleration on PIG, in 1974-87 and after 1994, that were separated by a period of quiescence (Joughin and others, 2003; Rignot and others 2008; Scott and others, 2009; Wingham and others, 2009). Jenkins and others (2010) found that, as of 1973, the grounding line of PIG had already retreated from the top of a subglacial topographic ridge, suggesting that the retreat throughout the observational record, as well as into the future, was likely to be an inevitable result of the wellknown marine ice-sheet instability (Hughes, 1981; Schoof, 2007) associated with deepening of the seabed inland of the ridge crest. This finding raised a question about the relative roles of contemporaneous ocean forcing and continuing icesheet response to an earlier event in controlling the current behaviour of the glacier. However, Joughin and others 

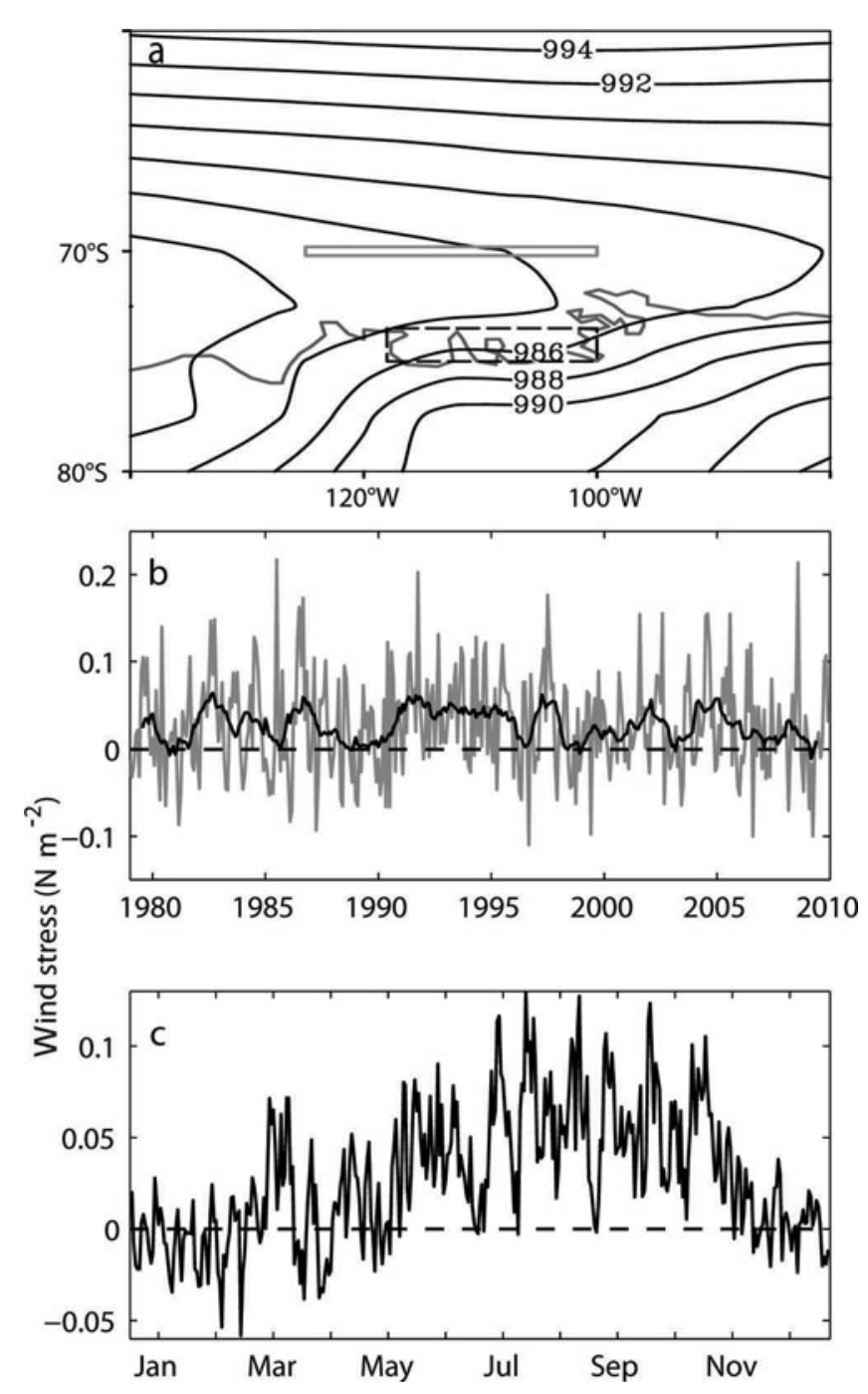

Fig. 1. (a) Climatological SLP (hPa) for June-August over the Amundsen and Bellingshausen Seas, with outline of the continent in blue. Red box shows the location $\left(70^{\circ} \mathrm{S}, 100-125^{\circ} \mathrm{W}\right)$ centered on the continental slope used for the zonal wind stress. Dashed box denotes the ASE. (b) Monthly zonal wind stress along with a 13 month running mean (bold line); (c) daily climatological wind stress from ERA-40/ERA-Interim 1979-2009. Positive values are westerly.

(2010) suggest that subtle topographic high points on the otherwise downward slope from the ridge crest could have halted grounding line retreat, at least temporarily, and that ocean forcing could have played a role in restarting the retreat in the 1990s. Furthermore, not only PIG but also Thwaites and Smith Glaciers thinned in the 1990s (Shepherd and others, 2002), and glaciers are thinning at present nearly everywhere along the Amundsen Sea margin of the WAIS despite varying bed geometry (e.g. Pritchard and others, 2009).

Thus, while the complex interaction between bed slope, glacier dynamics and ocean forcing remains to be fully understood, the evidence appears to be firm that changes in CDW inflow to the ASE, driven by changes in local wind forcing, have played a role in influencing the thinning and retreat of glaciers in the ASE. This raises the question of how the observed changes in winds in the ASE are related to larger-scale changes in atmospheric circulation. Thoma and others (2008) found that the correlation between local atmospheric circulation in the ASE and commonly used indices of the large-scale circulation, the Southern Annular Mode (SAM) index and the Southern Oscillation Index (SOI), was low. However, the causes of local wind changes cannot generally be ascribed to a single large-scale index, and the relevant dynamics probably depends on the season in which changes in CDW influx have occurred. In this paper, we explore in more detail the relationship between ASE winds, modelled CDW upwelling and the large-scale atmospheric circulation.

\section{DATA AND METHODS}

Thoma and others (2008) modelled CDW intrusions onto the ASE shelf using a regional ice-ocean model based on a version of the Miami Isopycnic Coordinate Ocean Model of Bleck and others (1992) adapted to include sub-ice-shelf cavities by Holland and Jenkins (2001). They forced the model with sea-level pressure (SLP) and sea surface temperature (SST) variations from the US National Centers for Environmental Prediction (NCEP) climate reanalysis data (Kalnay and others, 1996). We use their monthly model output of the thickness of CDW layers (isopycnic model layers 7 and 8) on the continental slope and on the inner shelf, near the margin of PIG, for the period 1980-2004. The continental shelf edge in the ASE region is oriented approximately east-west, and Thoma and others (2008) argued that increased westerlies would lead to enhanced CDW intrusion across the shelf. As a proxy for the westerlies they used a simple index for the geostrophic wind, based on the SLP difference across a box $\left(\sim 68-72^{\circ} \mathrm{S}\right)$ straddling the shelf edge. Here we use the zonal wind stress centred at $70^{\circ} \mathrm{S}$ and averaged between $100^{\circ} \mathrm{W}$ and $125^{\circ} \mathrm{W}$ (Fig. 1) as a more direct measure of atmospheric forcing. Both measures are highly correlated with one another and are in practice directly comparable.

A simple explanation for the relationship between westerly wind stress and CDW inflow is the northward Ekman transport of surface waters that drives an eastward geostrophic current and an associated upslope, on-shelf flow of CDW within the bottom boundary layer. While this process undoubtedly operates, the bulk of the inflow, which is focused on the shelf-edge troughs, is driven by more complex interactions between the temporally varying shelf-edge currents and the spatially varying topography, and is probably related to both the overall strength and the variability of the westerly wind stress (Klinck and Dinniman, 2010). Once on the continental shelf, CDW is transported into Pine Island Bay by a combination of the cyclonic circulation on the shelf and the deepening of the seabed along the axes of the main glacial troughs (Nitsche and others, 2007). An important caveat is that the resolution of the Thoma and others (2008) model (as well as that of the atmospheric forcing data), cannot explicitly capture the smaller-scale processes that control the on-shelf flow. While the isopycnic formulation of that model provides a natural framework in which to parameterize the transports associated with sub-gridscale eddies, the results remain to be corroborated by a model that resolves the eddy processes. These caveats on grid resolution notwithstanding, seasonal mean westerly wind stress is likely to be a physically meaningful measure of the atmospheric dynamics relevant to CDW inflow.

To obtain wind-stress data, and for analysis of the largescale climate fields, we use both NCEP2 (Kanamitsu and 
others, 2002) and a combination of ERA-40 (1979-2002) and ERA-Interim (2003-09) European Centre for MediumRange Weather Forecasts reanalysis (ERA) products (Uppala and others, 2005, 2008). For the variables we consider, ERA40 and ERA-Interim are indistinguishable during their overlap period (1989-2002). Following other recent work (Ding and others, 2011), in some figures we show ERA-40/ ERA-Interim data only, but the results are not dependent on which product is used. While problems in the reanalysis data have been noted, particularly at high southern latitudes (e.g. Bromwich and Fogt, 2004), due to changes in the availability of direct observations, we emphasize that the focus here is on the relationship between the reanalysis data and the results from an ocean model that has been forced by those same data; possible errors in the reanalysis datasets will thus have little influence on the results.

\section{RELATIONSHIP BETWEEN LOCAL WIND STRESS AND MODELLED CIRCUMPOLAR DEEP WATER INFLOW}

In the climatological mean, westerly wind stress at the ASE shelf edge occurs predominantly in fall through spring, with a maximum in late winter (Fig. 1). In austral summer, the wind stress is weak easterly. The true seasonal variability of CDW intrusions in the ASE is not known, due to the very limited available data. However, the model results of Thoma and others (2008) show the greatest quantity of CDW on the continental slope during spring, about 1 month after the climatological maximum in westerly wind stress, and a subsequent maximum on the inner shelf 1-2 months later. The lag between wind stress over the continental slope and modelled inner-shelf CDW layer thickness is quite consistent ( $\sim 2.5$ months) on both seasonal and interannual timescales, as clearly seen in a simple lag correlation plot (Fig. 2a). A spectral coherence calculation suggests the same phase lag also extends to decadal timescales (Fig. 2b and c), though this cannot be demonstrated to be statistically significant.

In the early 1990s, there is a significant increase in the thickness of modelled CDW in the ASE (Fig. 3), at least approximately coincident with the observation of resumed acceleration of PIG after 1994 (Joughin and others, 2003). This appears as a gradual increase beginning in the early 1990s, and a transition to a period of larger and more variable inner-shelf layer thickness around 1994. Although the mean monthly westerly wind stress (Fig. 1b) does not show such an obvious transition, there is a pronounced increase in austral fall and early winter in the early 1990s (March-June; Fig. 4). Indeed, while the seasonal maximum wind stress remains in winter and spring, the westerly wind stress in fall more than doubles between the 1980s and 1990s (Fig. 4). Layer thicknesses remain high through the end of the model period (2005), and similarly, the fall wind stress remains anomalous through this period. Importantly, the maximum layer thickness change between the 1980s and the 1990s to early 2000s on the continental slope also occurs in fall and early winter, and the maximum layer thickness change on the inner continental shelf occurs 1-3 months later (Fig. 3), indistinguishable from the average phase lag seen for seasonal and interannual variability. Thus, the significant increase in modelled CDW inflow beginning in the early 1990s appears to be the result of a corresponding shift in atmospheric conditions occurring in fall and early winter.
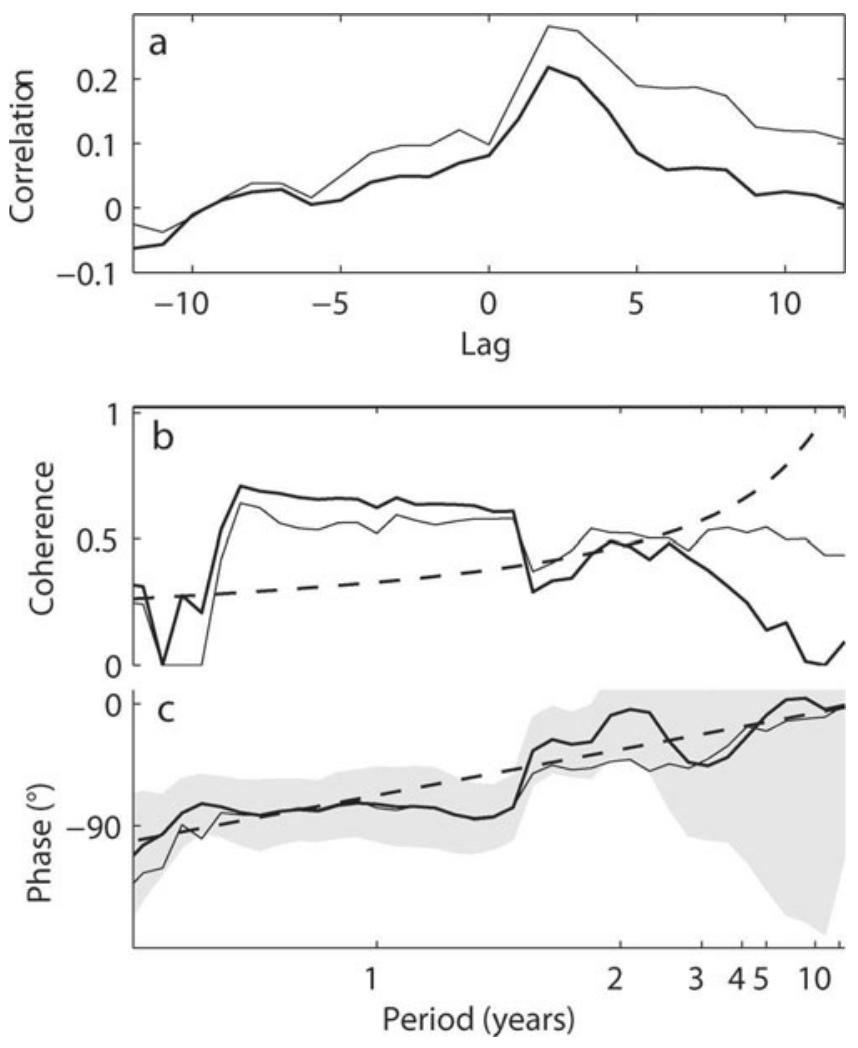

Fig. 2. Relationship between westerly wind stress near the continental slope and CDW layer thickness on the inner shelf in the ASE. (a) Correlation of monthly anomalies (mean seasonal cycle removed) of zonal wind stress with CDW layer thickness (layers 7 and 8 from Thoma and others, 2008), for December 1979 to November 2004. (b) Spectral coherence between wind stress and CDW inner-shelf layer thickness as a function of period. Dashed line shows 95\% confidence limit. (c) Phase of the coherence estimates, with 95\% uncertainties (shading). Dashed line shows phase for a constant 2.5 month lead of wind stress over CDW changes. Spectral coherence and phase calculated using the Thomson (1982) multi-taper method with a bandwidth of $\sim 0.6 \mathrm{a}^{-1}$. In each panel, thin lines are NCEP2 data, thick lines are ERA-40/ERA-Interim data.

\section{RELATIONSHIP BETWEEN LOCAL WIND STRESS AND LARGE-SCALE ATMOSPHERIC CIRCULATION}

We now turn to the causes of the observed variability and change in westerly wind stress in the ASE. The climatological seasonal variations are well understood, and are associated with the development of a pattern of increased SLP immediately to the north of the ASE, a corresponding weakening of the low-pressure trough (Fig. 1) along the ASE coastline, and a westward shift and contraction of the Amundsen Sea low (e.g. Van den Broeke, 2000; Simmonds and King, 2004). This pattern of variability is associated with the 'semi-annual oscillation', the amplitude of which is maximized near the ASE (Simmonds, 2003). A similar pattern of variability also occurs on longer timescales, and various mechanisms have been proposed depending on the season involved. Two commonly used indices of atmospheric circulation relevant to Antarctic climate variability are the SAM index (e.g. Marshall, 2003), which reflects the strength of the average circumpolar westerlies, and the SOI (e.g. Trenberth, 1984), which reflects conditions in the tropical Pacific. Ding and others (2011) have shown that 

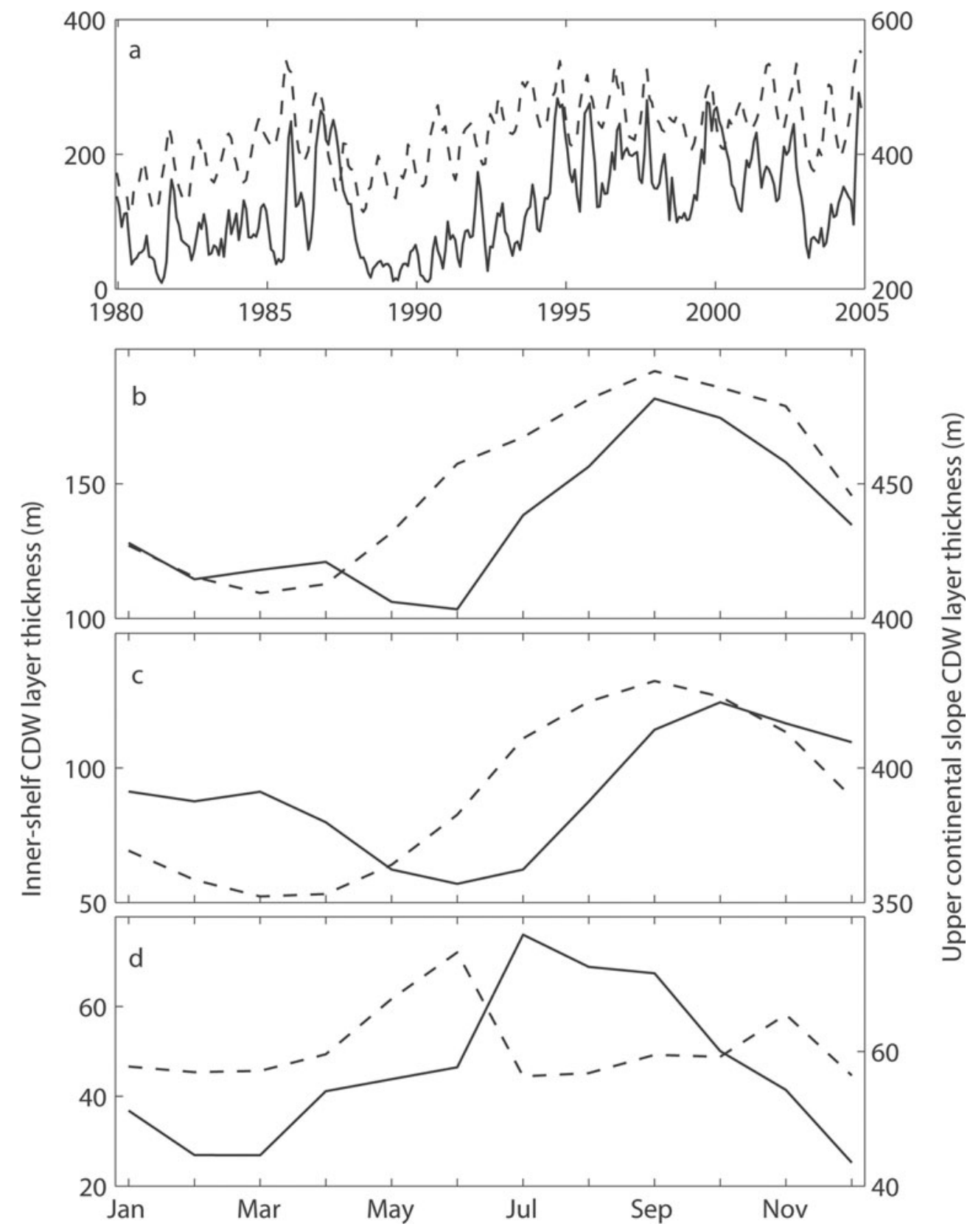

Fig. 3. Variations in thickness of CDW layers (layers 7 and 8) on the continental slope (dashed lines) and inner continental shelf (solid lines) from Thoma and others (2008). (a) Monthly averages from 1980 to 2004. (b) Seasonal climatology for the period 1990-99. (c) Seasonal climatology for the period 1980-89. (d) The difference between (b) and (c), significant at the 95\% confidence level for the fall (March-May) season, based on a two-tailed $t$ test.

correlation between the SOI and Amundsen Sea climate is linked more to variability in SST in the central tropical Pacific than in the eastern Pacific region. The Niño3.4 region $\left(5^{\circ} \mathrm{S}-5^{\circ} \mathrm{N}, 190-240^{\circ} \mathrm{E}\right)$ is a commonly used measure of central Pacific SST variability.

Table 1 shows the correlation between the zonal wind stress over the ASE shelf edge and various measures of largescale climate variability as a function of season. Statistically significant correlations in summer (December-February) are found only with the SAM index. In winter (June-August) and spring (September-November), statistically significant correlations are found with measures of tropical variability but not with the SAM index. In austral fall (March-May), significant correlations are found with both the SAM index and central tropical Pacific and South Pacific Convergence Zone (SPCZ) SSTs, as well as with the SOI.
The seasonal differences in correlation patterns shown in Table 1 support previous work on the causes of interannual variability in the Amundsen Sea region. Most studies of the SAM have focused on summer, during which a significant trend in the SAM has occurred (e.g. Thompson and Solomon, 2002). There is no significant trend in the winter or spring SAM index in the past 30 years, but there are large changes observed in Amundsen sector sea ice and Antarctic surface temperatures in those seasons (Comiso and Nishio, 2008; Steig and others, 2009) that have been linked with changes in tropical Pacific SSTs (Ding and others, 2011; Schneider and others, 2011). Turner and others (2009) showed that recent trends in sea ice as well as changes in SLP and geopotential height in the Amundsen sector are significant in the fall in the last 30 years, and suggested that those changes, reminiscent of the climatological fall-to-winter change in the Amundsen 
Sea low, could be explained by changes in the SAM. While this is consistent with our finding of a significant correlation between the fall SAM index and the ASE westerlies, this result is quite sensitive to the season chosen: in the fall/early-winter season (April-June), there is no correlation with the SAM; in contrast, wind stress in March-May and April-June is consistently at least as highly correlated with indices of tropical variability as with the SAM.

Figure 5 shows maps of the interannual correlation between ASE zonal wind stress and SLP, the upper-troposphere stream function and SST for austral fall (March-May). The most prominent feature in SLP is a significant correlation in the Amundsen Sea sector of the Southern Ocean. The SLP anomalies are the surface expression of a deep coherent tropospheric circulation, with corresponding geopotential height anomalies in the middle and upper troposphere. The dynamical connection between ASE wind stress and the tropical Pacific is apparent in the correlation with the stream function at the $200 \mathrm{hPa}$ level (Fig. 5b), which shows a sequence of positive and negative correlation centres extending from the central equatorial Pacific to the far south Pacific. These patterns, along with the nearly equivalent barotropic structure of the high-latitude geopotential height anomalies, are characteristic of a stationary Rossby wave response to tropical SST forcing (e.g. Gill, 1980; Hoskins and Karoly, 1981; Mo and Higgins, 1998). Correspondingly, the correlation between ASE westerly wind stress and SST features a positive SST anomaly in the central tropics (Fig. 5c).

The dynamics responsible for the teleconnection between the tropical Pacific and the south Pacific are well established (e.g. Sardeshmukh and Hoskins 1988; Lachlan-Cope and Connolley, 2006): anomalously high SSTs in the central Pacific force an increase in tropical convection in regions of strong potential vorticity gradients (associated with the subtropical jet east of Australia), which creates a strong Rossby wave response along a great-circle path towards the Amundsen Sea. Indeed, Ding and others (2011) showed that modest positive tropical SST anomalies in the central Pacific, very similar in pattern to that shown in Figure 5c, force atmospheric circulation anomalies consistent in pattern and amplitude with those shown in Figure $5 \mathrm{a}$ and b, including in the Amundsen Sea region.

The same physics that relates tropical SSTs with interannual anomalies in ASE zonal wind stress in March-May also appears to be responsible for the decadal changes in

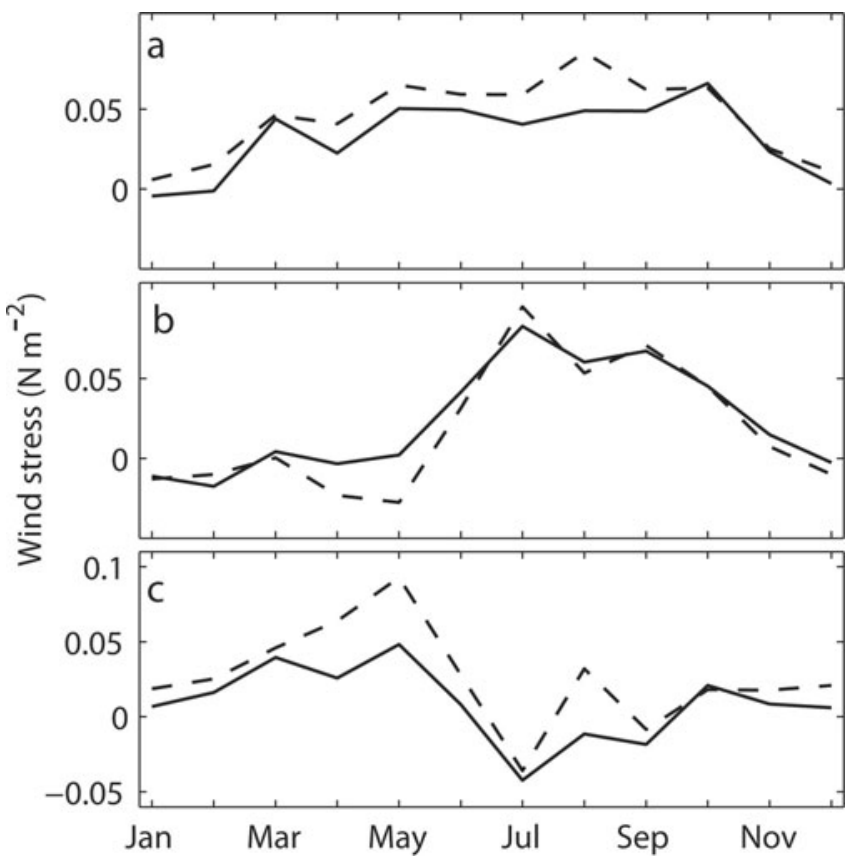

Fig. 4. Seasonal wind-stress climatology from NCEP2 (dashed lines) and ERA-40 (solid lines) for (a) 1990-99 (b) 1980-89 and (c) their difference. Although the mean wind-stress maximum occurs in the same seasons (winter and spring) in both periods, the seasonal mean westerly wind stress more than doubled in the fall between the 1980s and 1990s.

wind stress that account for the modelled changes in CDW layer thickness. Figure 6 shows the changes in SLP, upperlevel stream function and SST between the 1980s and the 1990s that accompany the CDW layer thickness and windstress changes shown in Figures 3 and 4. The patterns of surface and upper-level circulation and SST changes associated with the decadal changes in the ASE zonal winds are strikingly similar to the pattern of interannual correlations. This is not surprising, because decade-to-decade changes in the tropical Pacific are in part a reflection of differences in the character of El Niño Southern Oscillation (ENSO) variability. For example, an important difference between the large El Niño event in 1982/83 and that in 1997/98 is that SST anomalies associated with the former were restricted to the eastern Pacific, whereas the latter involved

Table 1. Correlations between zonal wind stress (ERA-40/ERA-Interim) near the shelf edge of the ASE, and the SAM index, SOI and SST in the tropical and subtropical Pacific (ERSST3), for the period 1979-2009, for different 3 month seasons (DJF: December-February; MAM: MarchMay; AMJ: April-June; JJA: June-August; SON: September-November) and the annual mean. Latitude and longitude ranges for the SSTs are: Eastern: $6^{\circ} \mathrm{S}-6^{\circ} \mathrm{N}, 240-280^{\circ} \mathrm{E}$; Central: $6^{\circ} \mathrm{S}-6^{\circ} \mathrm{N}, 160-240^{\circ} \mathrm{E}$; Niño3.4: $6^{\circ} \mathrm{S}-6^{\circ} \mathrm{N}, 190-240^{\circ} \mathrm{E} ; \mathrm{SPCZ}$ : 8-20 $0^{\circ}$ S, $180-240^{\circ} \mathrm{E}$. Bold numbers indicate significant correlation above the $95 \%$ level, italics at the $90-95 \%$ confidence level. Autocorrelation in the wind-stress data is $<0.1$, so correction of significance levels for autocorrelation is negligible

\begin{tabular}{|c|c|c|c|c|c|c|}
\hline & \multicolumn{6}{|c|}{ Season } \\
\hline & DJF & MAM & AMJ & JJA & SON & Annual \\
\hline SAM index & 0.34 & 0.35 & 0.11 & 0.07 & 0.09 & 0.05 \\
\hline SOI & -0.20 & -0.36 & -0.36 & -0.31 & -0.61 & -0.60 \\
\hline Eastern tropical Pacific SST & 0.21 & 0.19 & 0.20 & 0.13 & 0.35 & 0.36 \\
\hline Central tropical Pacific SST & 0.19 & 0.36 & 0.43 & 0.34 & 0.47 & 0.53 \\
\hline Niño3.4 SST & 0.20 & 0.33 & 0.40 & 0.37 & 0.45 & 0.55 \\
\hline SPCZ SST & 0.14 & 0.49 & 0.33 & 0.14 & 0.26 & 0.40 \\
\hline
\end{tabular}


a

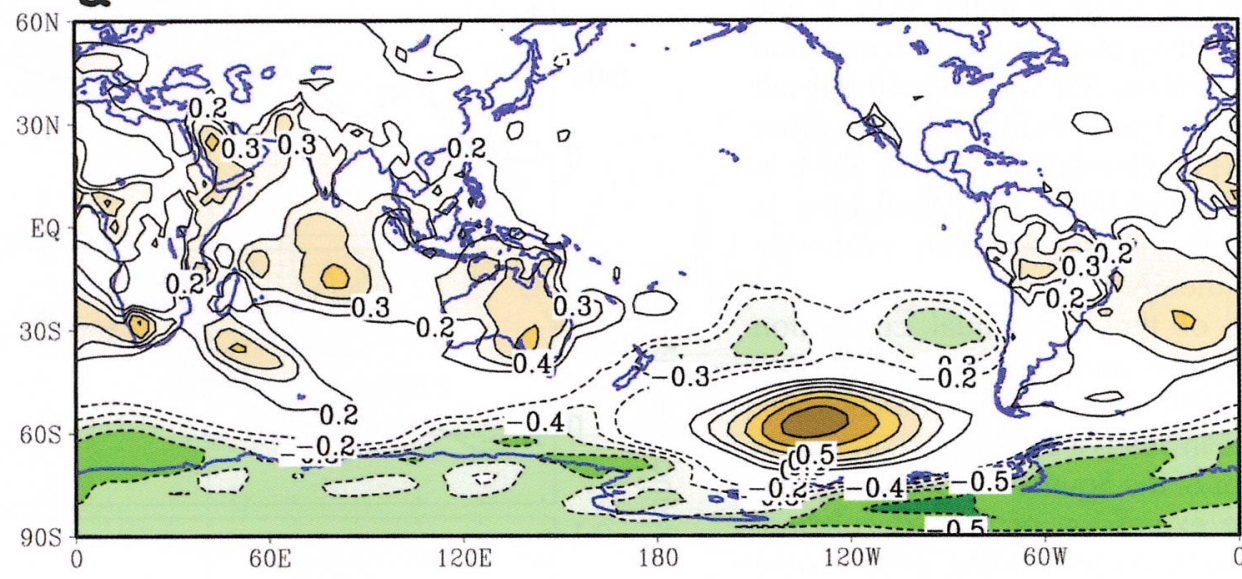

b
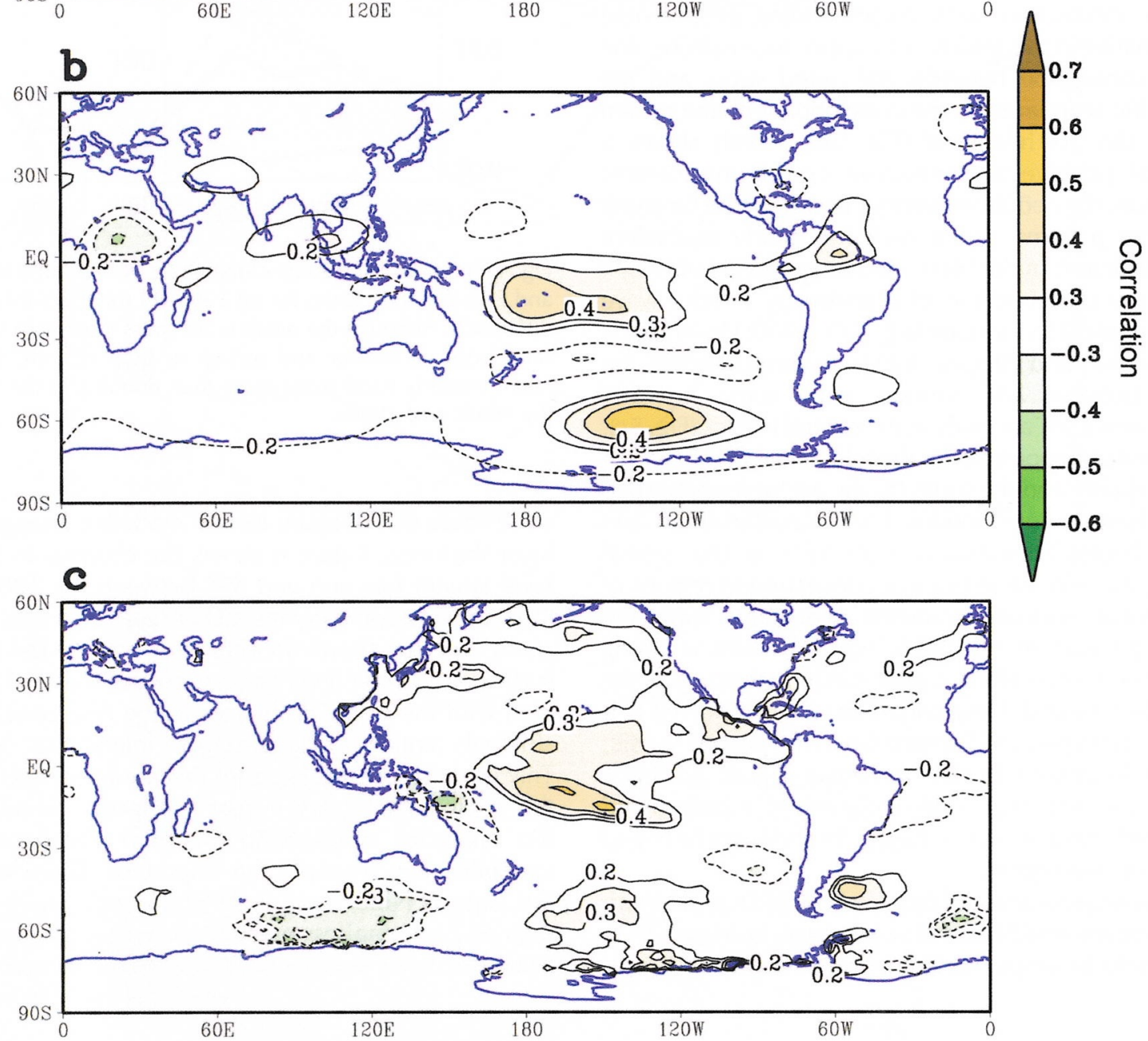

Fig. 5. Correlation between zonal wind stress in the ASE region (red box in Fig. 1) in austral fall (March-May) and (a) SLP, (b) upper-troposphere $(200 \mathrm{hPa}$ ) stream function and (c) SST. Data are from ERA-40/ERA-Interim and ERSST3 (extended reconstructed SST; Smith and others, 2008) for the period 1979-2009. Areas of statistically significant correlation are shaded ( $\sim 0.35$ corresponds to $95 \%$ confidence level).

significant warming in the central Pacific, the more important region for exciting a poleward-propagating Rossby wave response. Trenberth and Hoar (1997) noted that another difference between the 1980s and the 1990s is that the La Niña events of the latter decade were relatively weak. Hence, it appears that tropical SST forcing is responsible for a significant fraction of both interannual variability and decade-to-decade change in ASE zonal wind stress. Tropical SST forcing thus plays an important role in influencing the amount of warm CDW that flows across the continental shelf to bathe the PIG ice shelf and the floating termini of other outlet glaciers in the ASE.

\section{DISCUSSION}

The results above show that both interannual variability and longer-term changes in westerly wind stress in the ASE, relevant to forcing CDW inflow to the continental shelf, are significantly influenced by conditions in the tropics, particularly during the non-summer seasons. In the annual mean, as 
a
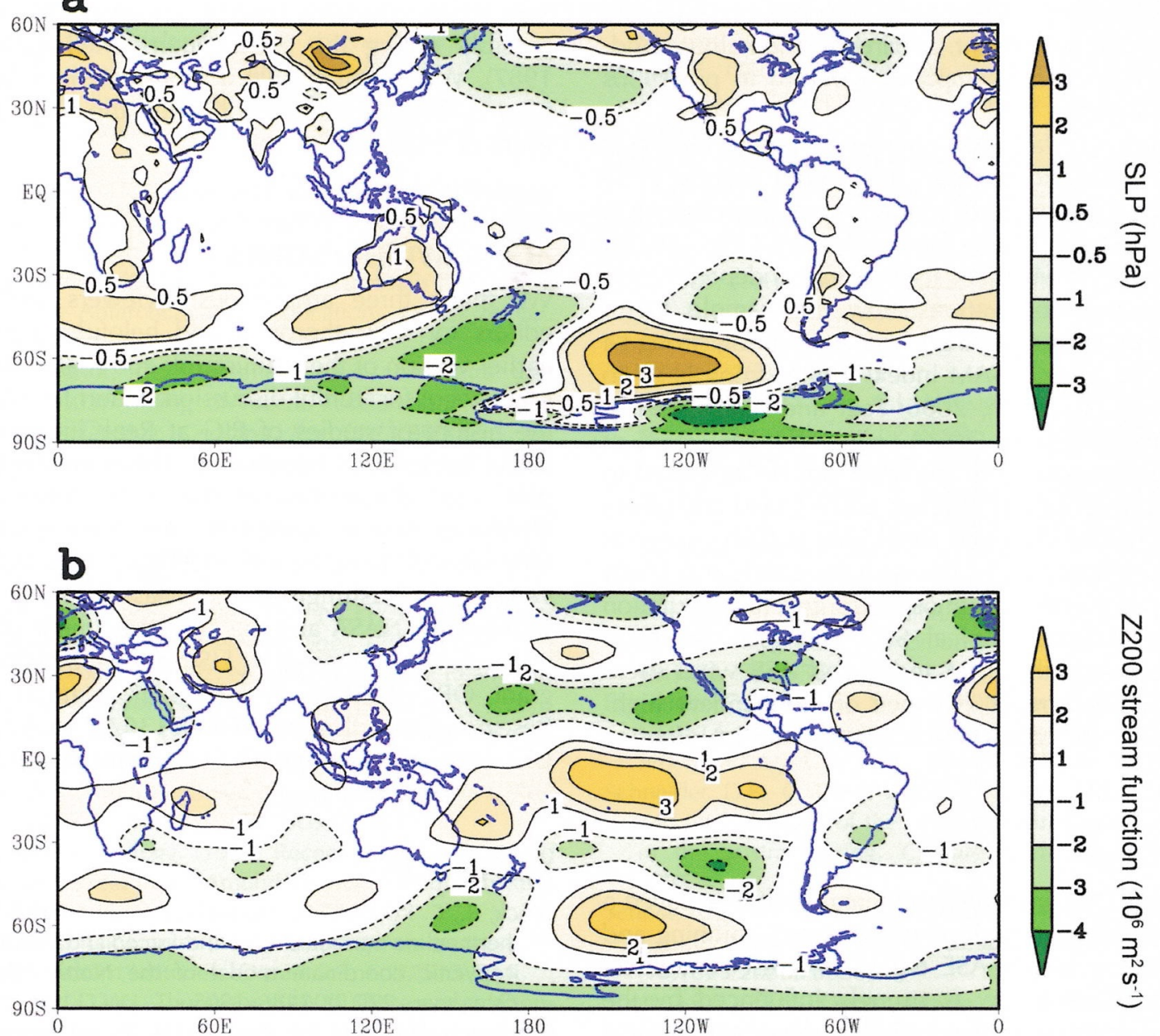

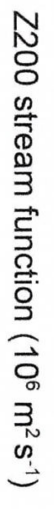

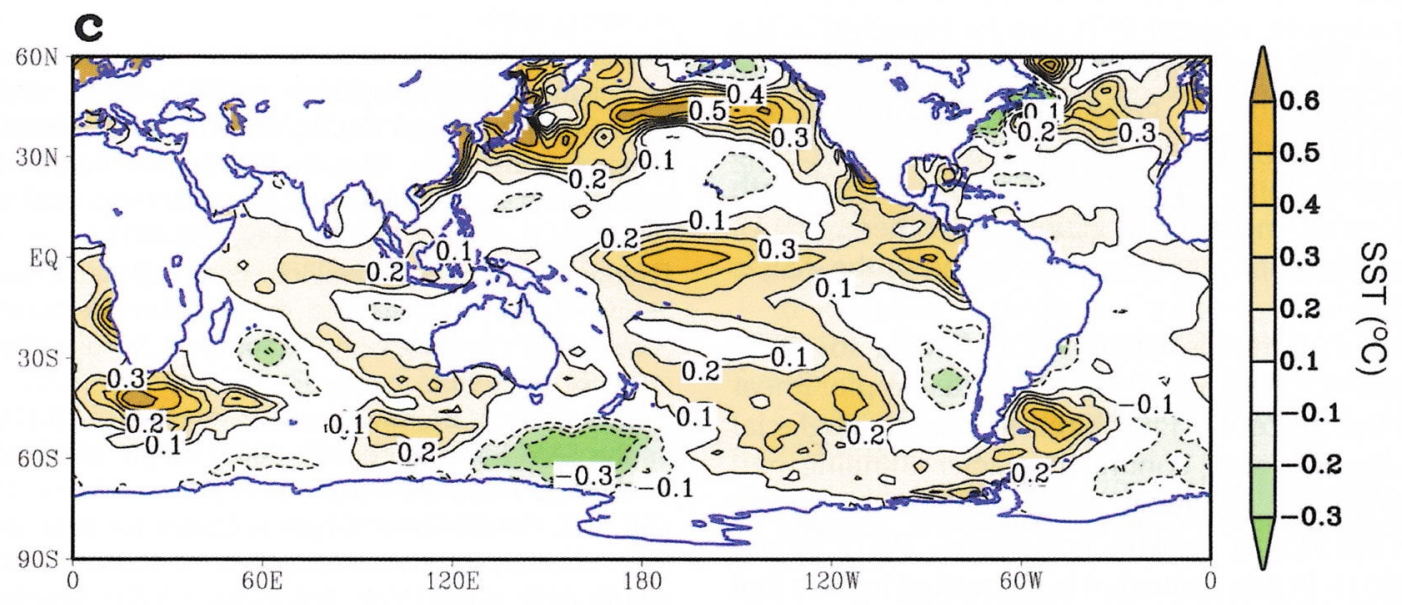

Fig. 6. Change in decadal mean (a) SLP, (b) upper-troposphere (200 hPa) stream function (Z200) and (c) SST in austral fall (March-May) between 1980-89 and 1990-99 from ERA-40 and ERSST3 data.

much as $30 \%$ or more of the variance in zonal ASE wind stress can be attributed to tropical forcing, depending on which measure of tropical variability is used. Regional, highlatitude atmospheric processes are also important and must dominate the unforced variability. We cannot rule out an independent role for the SAM, but only in the summer is there evidence that the SAM plays a greater role than that of tropical forcing. The largest changes in wind stress occur in fall and early winter, when tropical forcing is clearly at least comparable, and probably dominant.
The distinction between low- and high-latitude forcing of the ASE wind stress has significant implications for our understanding of both recent and future changes in CDW inflow, and therefore of the past and future evolution of PIG and other outlet glaciers in the ASE. Recent changes in the SAM in summer have been widely attributed to radiative forcing resulting from the decline in stratospheric ozone (Thompson and Solomon, 2002; Gillett and Thompson, 2003; Son and others, 2008). If changes in the ASE winds in fall were similarly attributed to ozone-related SAM changes, 
this would imply that as the ozone hole recovers over the next few decades, the current, apparently anomalous windfield pattern will change, implying a return to pre-1990s CDW inflow strength.

The attribution of fall SAM changes to ozone forcing is somewhat problematic because this would require a 36 month lagged response to spring ozone depletion (e.g. Keeley and others 2007; Sigmond and Fyfe, 2010). Furthermore, the SAM index itself is not independent of tropical conditions: observations show, for example, that a positive SAM index is more likely to occur during strong La Niña years, and a weak SAM index during strong El Niño years (Fogt and Bromwich, 2006; Fogt and others, 2011). L'Heureux and Thompson (2006) concluded that $~ 25 \%$ of the interannual variability in the SAM can be attributed to ENSO variability in austral summer, while Grassi and others (2005) show that the observed zonal SAM pattern change at $500 \mathrm{hPa}$ geopotential heights between the 1980s and 1990s can be simulated with an atmospheric general circulation model using observed tropical SST forcing alone. Thus, correlation between the SAM index and ASE wind stress does not in itself provide evidence of independent highlatitude forcing. In contrast, the role of tropical forcing is unequivocal.

\section{CONCLUSIONS}

Flow of warm CDW onto the continental shelf has played a critical role in the high melt rates and recent thinning and retreat of glaciers in the ASE region of West Antarctica. Variability in CDW inflow is strongly influenced by the westerly wind stress over the continental slope, and tropical SST forcing has played an important, if not dominant, role in recent changes in the zonal wind regime in the ASE. Continued changes in tropical SSTs can be expected in the future, due to increased global radiative forcing from anthropogenic greenhouse gases, and warming in the central tropics is particularly pronounced in most IPCC (Intergovernmental Panel on Climate Change) AR4 (Fourth Assessment Report) model runs (Ding and others, 2011), suggesting that the current wind-stress regime in the ASE is likely to persist.

We caution that the link from wind forcing to CDW inflow changes to glacier retreat is not a simple linear process, and that once the PIG retreated past a subglacial ridge some decades ago, continued glacier thinning and retreat was probably inevitable even without the recent changes in wind forcing (Jenkins and others, 2010; Jacobs and others, 2011). In this context, it is interesting to note that significant warming in the central tropical Pacific last occurred in the 1940s, and ice-core evidence indicates that the impact on climate in the Amundsen Sea sector of Antarctica was comparable with what has been observed recently (Schneider and Steig, 2008). This suggests that tropical SST forcing during the 1940s is a viable candidate for the initiation of the current period of change in the Amundsen Sea ice shelves, which clearly was underway at least by the 1970s (Jenkins and others, 2010). Photographic evidence shows that in 1947 the PIG ice shelf was only slightly more advanced than in the early 1970s, but that a large area of icebergs and sea ice extended seaward of the ice front, which may be evidence of significant calving over the preceding decade (Rignot, 2002). There is also independent evidence from sediment cores that a larger ice shelf may have occupied the ASE at some time prior to this, possibly during the 20th century (Kellogg and Kellogg, 1987). We speculate that a more extensive ice shelf may have partially collapsed following the very large El Niño event of 1939-42.

\section{ACKNOWLEDGEMENTS}

We thank three anonymous reviewers and the journal editors for their thorough and helpful comments on an earlier version of the manuscript, and Marcel Küttel and Joe MacGregor for fruitful discussion. Mauri Pelto's summary of the history of studies of PIG at RealClimate.org provided useful background information. The manuscript stemmed in part from discussions at the 2010 Advanced Climate Dynamics course funded by the Norwegian Centre for International Cooperation in Higher Education, the University of Washington, the Massachusetts Institute of Technology, NASA and the US Department of Energy. This research was supported by US National Science Foundation grant OPP-0837988 to E.J.S., UK Natural Environment Research Council grant NE/G001367/1 to A.J., and by the University of Washington's Quaternary Research Center.

\section{REFERENCES}

Bleck, R., C. Rooth, D.M. Hu and L.T. Smith. (1992) Salinity-driven thermocline transients in a wind-forced and thermohaline forced isopycnic coordinate model of the North Atlantic. J. Phys. Oceanogr., 22(12), 1486-1505.

Bromwich, D.H. and R.L. Fogt. (2004) Strong trends in the skill of the ERA-40 and NCEP NCAR reanalyses in the high and midlatitudes of the southern hemisphere. J. Climate, 17(23), 4603-4619.

Comiso, J.C. and F. Nishio. (2008) Trends in the sea ice cover using enhanced and compatible AMSR-E, SSM/I, and SMMR data. J. Geophys. Res., 113(C2), C02S07. (10.1029/2007JC004257.)

Ding, Q., E.J. Steig, D.S. Battisti and M. Küttel. (2011) Winter warming in West Antarctica caused by central tropical Pacific warming. Nature Geosci., 4(6), 398-403.

Fogt, R.L. and D.H. Bromwich. (2006) Decadal variability of the ENSO teleconnection to the high-latitude South Pacific governed by coupling with the Southern Annular Mode. J. Climate, 19(6), 979-997.

Fogt, R.L., D.H. Bromwich and K.M. Hines. (2011) Understanding the SAM influence on the South Pacific ENSO teleconnection. Climate Dyn., 36(7-8), 1555-1576.

Gill, A.E. (1980) Some simple solutions for heat-induced tropical circulation. Q. J. R. Meteorol. Soc., 106(449), 447-462.

Gillett, N.P. and D.W.J. Thompson. (2003) Simulation of recent Southern Hemisphere climate change. Science, 302(5643), 273-275.

Grassi, B., G. Redaelli and G. Visconti. (2005) Simulation of Polar Antarctic trends: influence of tropical SST. Geophys. Res. Lett., 32(23), L23806. (10.1029/2005GL023804.)

Holland, D.M. and A. Jenkins. (2001) Adaptation of an isopycnic coordinate ocean model for the study of circulation beneath ice shelves. Mon. Weather Rev., 129(8), 1905-1927.

Hoskins, B.J. and D.J. Karoly. (1981) The steady linear response of a spherical atmosphere to thermal and orographic forcing. J. Atmos. Sci., 38(14), 2150-2163.

Hughes, T.J. (1979) Reconstruction and disintegration of ice sheets for the CLIMAP 18000 and 125000 years B.P. experiments: theory. J. Glaciol., 24(90), 493-495.

Hughes, T.J. (1981) Correspondence. The weak underbelly of the West Antarctic ice sheet. J. Glaciol., 27(97), 518-525. 
Jacobs, S.S., H.H. Hellmer, C.S.M. Doake, A. Jenkins and R.M. Frolich. (1992) Melting of ice shelves and the mass balance of Antarctica. J. Glaciol., 38(130), 375-387.

Jacobs, S.S., H.H. Hellmer and A. Jenkins. (1996) Antarctic ice sheet melting in the southeast Pacific. Geophys. Res. Lett., 23(9), 957-960.

Jacobs, S.S., A. Jenkins, C.F. Giulivi and P. Dutrieux. (2011) Stronger ocean circulation and increased melting under Pine Island Glacier ice shelf. Nature Geosci., 4(8), 519-523.

Jenkins, A. and 6 others. (2010) Observations beneath Pine Island Glacier in West Antarctica and implications for its retreat. Nature Geosci., 3(7), 468-472.

Joughin, I., E. Rignot, C.E. Rosanova, B.K. Lucchitta and J. Bohlander. (2003) Timing of recent accelerations of Pine Island Glacier, Antarctica. Geophys. Res. Lett., 30(13), 1706. (10.1029/2003GL017609.)

Joughin, I., B.E. Smith and D.M. Holland. (2010) Sensitivity of 21st century sea level to ocean-induced thinning of Pine Island Glacier, Antarctica. Geophys. Res. Lett., 37(20), L20502. (10.1029/2010GL044819.)

Kalnay, E. and 21 others. (1996) The NCEP/NCAR 40-year reanalysis project. Bull. Am. Meteorol. Soc., 77(3), 437-471.

Kanamitsu, M. and 6 others. (2002) NCEP-DOE AMIP-II Reanalysis (R-2). Bull. Am. Meteorol. Soc., 83(11), 1631-1643.

Keeley, S.P.E., N.P. Gillett, D.W.J. Thompson, S. Solomon and P.M. Forster. (2007) Is Antarctic climate most sensitive to ozone depletion in the middle or lower stratosphere? Geophys. Res. Lett., 34(22), L22812. (10.1029/2007GL031238.)

Kellogg, T.B. and D.E. Kellogg. (1987) Recent glacial history and rapid ice stream retreat in the Amundsen Sea. J. Geophys. Res., 92(B9), 8859-8864.

Klinck, J.M. and M.S. Dinniman. (2010) Exchange across the shelf break at high southern latitudes. Ocean Sci., 6(2), 513-514.

L'Heureux, M.L. and D.W.J. Thompson. (2006) Observed relationships between the El Niño-Southern Oscillation and the extratropical zonal-mean circulation. J. Climate, 19(2), 276-287.

Lachlan-Cope, T. and W. Connolley. (2006) Teleconnections between the tropical Pacific and the Amundsen-Bellinghausen Sea: role of the El Niño/Southern Oscillation. J. Geophys. Res., 111(D23), D23101. (10.1029/2005JD006386.)

Lingle, C.S. and J.A. Clark. (1979) Antarctic ice-sheet volume at 18000 years B.P. and Holocene sea-level changes at the West Antarctic margin. J. Glaciol., 24(90), 213-230.

Lythe, M.B., D.G. Vaughan and BEDMAP consortium. (2001) BEDMAP: a new ice thickness and subglacial topographic model of Antarctica. J. Geophys. Res., 106(B6), 11 335-11 351.

Marshall, G.J. (2003) Trends in the Southern Annular Mode from observations and reanalyses. J. Climate, 16(24), 4134-4143.

Mo, K.C. and R.W. Higgins. (1998) The Pacific-South American modes and tropical convection during the Southern Hemisphere winter. Mon. Weather Rev., 126(6), 1581-1596.

Naish, T. and 55 others. (2009) Obliquity-paced Pliocene West Antarctic ice sheet oscillations. Nature, 458(7236), 322-328.

Nitsche, F.O., S.S. Jacobs, R.D. Larter and K. Gohl. (2007) Bathymetry of the Amundsen Sea continental shelf: implications for geology, oceanography, and glaciology. Geochem. Geophys. Geosyst., 8(Q10), Q10009. (10.1029/2007GC001694.)

Payne, A.J., A. Vieli, A. Shepherd, D.J. Wingham and E. Rignot. (2004) Recent dramatic thinning of largest West Antarctic ice stream triggered by oceans. Geophys. Res. Lett., 31(23), L23401. (10.1029/2004GL021284.)

Pollard, D. and R.M. DeConto. (2009) Modelling West Antarctic ice sheet growth and collapse through the past five million years. Nature, 458(7236), 329-332.

Pritchard, H.D., R.J. Arthern, D.G. Vaughan and L.A. Edwards. (2009) Extensive dynamic thinning on the margins of the Greenland and Antarctic ice sheets. Nature, 461(7266), 971-975.
Rignot, E.J. (1998) Fast recession of a West Antarctic glacier. Science, 281(5376), 549-551.

Rignot, E. (2001) Evidence for rapid retreat and mass loss of Thwaites Glacier, West Antarctica. J. Glaciol., 47(157), 213-222.

Rignot, E. (2002) Ice-shelf changes in Pine Island Bay, Antarctica, 1947-2000. J. Glaciol., 48(161), 247-256.

Rignot, E. (2008) Changes in West Antarctic ice stream dynamics observed with ALOS PALSAR data. Geophys. Res. Lett., 35(12), L12505. (10.1029/2008GL033365.)

Rignot, E. and 6 others. (2008) Recent Antarctic ice mass loss from radar interferometry and regional climate modelling. Nature Geosci., 1(2), 106-110.

Sardeshmukh, P.D. and B.J. Hoskins. (1988) The generation of global rotational flow by steady idealized tropical divergence. J. Atmos. Sci., 45(7), 1228-1251.

Scherer, R.P., A. Aldahan, S. Tulaczyk, G. Possnert, H. Engelhardt and B. Kamb. (1998) Pleistocene collapse of the West Antarctic ice sheet. Science, 281(5373), 82-85.

Schmeltz, M., E. Rignot, T.K. Dupont and D.R. MacAyeal. (2002) Sensitivity of Pine Island Glacier, West Antarctica, to changes in ice-shelf and basal conditions: a model study. J. Glaciol., 48(163), 552-558.

Schneider, D.P. and E.J. Steig. (2008) Ice cores record significant 1940s Antarctic warmth related to tropical climate variability. Proc. Natl Acad. Sci. USA (PNAS), 105(34), 12 154-12 158.

Schneider, D.P., C. Deser and Y. Olumura. (2011) An assessment and interpretation of the observed warming of West Antarctica in the austral spring. Climate Dyn. (10.1007/s00382-0100985-x.)

Schoof, C. (2007) Ice sheet grounding line dynamics: steady states, stability, and hysteresis. J. Geophys. Res., 112(F3), F03S28. (10.1029/2006JF000664.)

Scott, J.B.T., G.H. Gudmundsson, A.M. Smith, R.G. Bingham, H.D. Pritchard and D.G. Vaughan. (2009) Increased rate of acceleration on Pine Island Glacier is strongly coupled to thinning induced changes in driving stress. Cryosphere, 3(1), 125-131.

Shepherd, A., D. Wingham and J.A. Mansley. (2002) Inland thinning of the Amundsen Sea sector, West Antarctica. Geophys. Res. Lett., 29(10), 1364. (10.1029/2001GL014183.)

Shepherd, A., D. Wingham and E. Rignot. (2004) Warm ocean is eroding West Antarctic Ice Sheet. Geophys. Res. Lett., 31(23), L23404. (10.1029/2004GL021106.)

Sigmond, M. and J.C. Fyfe. (2010) Has the ozone hole contributed to increased Antarctic sea ice extent? Geophys. Res. Lett., 37(18), L18502. (10.1029/2010GL044301.)

Simmonds, I. (2003) Modes of atmospheric variability over the Southern Ocean. J. Geophys. Res., 108(C4), 8078. (10.1029/ 2000JC000542.)

Simmonds, I. and J.C. King. (2004) Global and hemispheric climate variations affecting the Southern Ocean. Antarct. Sci., 16(4), 401-413.

Smith, T.M., R.W. Reynolds, T.C. Peterson and J. Lawrimore. (2008) Improvements to NOAA's Historical Merged Land-Ocean Surface Temperature Analysis (1880-2006). J. Climate, 21(10), 2283-2296.

Son, S.-W. and 9 others. (2008) The impact of stratospheric ozone recovery on the Southern Hemisphere westerly jet. Science, 320(5882), 1486-1489.

Steig, E.J., D.P. Schneider, S.D. Rutherford, M.E. Mann, J.C. Comiso and D.T. Shindell. (2009) Warming of the Antarctic ice-sheet surface since the 1957 International Geophysical Year. Nature, 457(7228), 459-462.

Thoma, M., A. Jenkins, D. Holland and S. Jacobs. (2008) Modelling Circumpolar Deep Water intrusions on the Amundsen Sea continental shelf, Antarctica. Geophys. Res. Lett., 35(18), L18602. (10.1029/2008GL034939.)

Thomas, R.H., E.J. Rignot, K. Kanagaratnam, W.B. Krabill and G. Casassa. (2004) Force-perturbation analysis of Pine Island 
Glacier, Antarctica, suggests cause for recent acceleration. Ann. Glaciol., 39, 133-138.

Thompson, D.W.J. and S. Solomon. (2002) Interpretation of recent Southern Hemisphere climate change. Science, 296(5569), 895-899.

Thomson, D.J. (1982) Spectrum estimation and harmonic analysis. IEEE Proc., 70, 1055-1096.

Trenberth, K.E. (1984) Signal versus noise in the Southern Oscillation. Mon. Weather Rev., 112(2), 326-332.

Trenberth, K.E. and T.J. Hoar. (1997) El Niño and climate change. Geophys. Res. Lett., 24(23), 3057-3060.

Turner, J. and 8 others. (2009) Non-annular atmospheric circulation change induced by stratospheric ozone depletion and its role in the recent increase of Antarctic sea ice extent. Geophys. Res. Lett., 36(8), L08502. (10.1029/2009GL037524.)
Uppala, S.M. and 45 others. (2005) The ERA-40 re-analysis. Q. J. R. Meteorol. Soc., 131(612), 2961-3212.

Uppala, S., D. Dee, S. Kobayashi, P. Berrisford and A. Simmons. (2008) Towards a climate data assimilation system: status update of ERA-Interim. ECMWF NewsI. 115, 12-18.

Van den Broeke, M.R. (2000) The semiannual oscillation and Antarctic climate. Part 4: a note on sea ice cover in the Amundsen and Bellingshausen Seas. Int. J. Climatol., 20(4), 455-462.

Wingham, D.J., A.L. Ridout, R. Scharroo, R.J. Arthern and C.K. Shum. (1998) Antarctic elevation change from 1992 to 1996. Science, 282(5388), 456-458.

Wingham, D.J., D.W. Wallis and A. Shepherd. (2009) Spatial and temporal evolution of Pine Island Glacier thinning, 1995-2006. Geophys. Res. Lett., 36(17), L17501. (10.1029/2009GL039126.) 